\title{
Vesetranszplantáció utáni szénhidrátanyagcsere-változások és annak hatásai a cardiovascularis rizikóra
}

\author{
Borda Bernadett dr. ${ }^{1}$. Szederkényi Edit dr. ${ }^{1}$. Hódi Zoltán dr. ${ }^{1}$ \\ Ottlakán Aurél dr. ${ }^{1}$ - Szabó Viktor dr. ${ }^{2}$ - Lázár György dr. ${ }^{1}$
}

Szegedi Tudományegyetem, Általános Orvostudományi Kar, 'Sebészeti Klinika,

${ }^{2}$ Családorvosi Intézet és Rendelő, Szeged

Bevezetés: A transzplantáció utáni halálozások legfőbb okai a cardiovascularis betegségek, amelyeknek egyik legfőbb rizikófaktora a diabetes mellitus.

Célkitüzés: Vizsgálatunk célja volt, hogy felmérjük az újonnan kialakult diabetes mellitus előfordulási gyakoriságát és hatását az allograft funkciójára, valamint a HEART-pont alapján a cardiovascularis rizikó kockázatát.

Módszer: Összesen 44 beteget vontunk be a vizsgálatba, akiknél értékeltük az alapadatokat, majd OGTT-vizsgálatot követően a betegeket három csoportba soroltuk, normál, emelkedett éhomi vércukorszint/csökkent glükóztolerancia és (az) újonnan kialakult diabetes mellitus. Az inzulinrezisztenciát HOMA-IR alapján értékeltük. Vizsgáltuk a vesefunkciót, valamint a HEART-pont alapján a cardiovascularis rizikót.

Eredmények: Az alapadatok tekintetében a hideg ischaemiás idő $(\mathrm{p}=0,016)$, a testsúly $(\mathrm{p}=0,035)$, a BMI $(\mathrm{p}=0,025)$ és a $\mathrm{HbA}_{\mathrm{lc}}(\mathrm{p}=0,0024)$ szignifikánsan különböztek a normál és a diabeteses betegek között. A vesefunkció tekintetében a szérumkreatinin- $(\mathrm{p}=0,0013)$, eGFR- $(\mathrm{p}=0,0026)$, valamint karbamid- $(\mathrm{p}=0,0157)$ értékek szignifikánsan különböztek a normál és a diabeteses betegek között. A HOMA-IR tekintetében a normál és a diabeteses betegek között szignifikáns különbség volt $(1,69 \pm 0,51$ vs. 6,46 $\pm 1,42 ; p=0,0017)$.

Következtetés: A cardiovascularis kockázat csökkenthető, az allograft túlélése növelhető a diabetes mellitus időben történő felismerésével és kezelésével.

Orv Hetil. 2017; 158(38): 1512-1516.

Kulcsszavak: vesetranszplantáció, újonnan kialakult diabetes mellitus, cardiovascularis rizikó

\section{Changes in carbohydrate metabolism after kidney transplantation and their effects on cardiovascular risk}

Introduction: Cardiovascular disease is the major cause of deaths after transplantation, with diabetes mellitus being the main risk factor in development.

Aim: The aim of our study was to assess the prevalence of new onset diabetes mellitus in connection with the cardiovascular risk predicted by the HEART Score.

Method: 44 patients were involved in our study; after overview of baseline data, OGTT was performed, followed by patient classification into the following groups: normal, impaired fasting glucose/impaired glucose tolerance, and new onset diabetes mellitus. Insulin resistance and kidney function were also assessed.

Results: Concerning baseline data, cold ischemic time $(\mathrm{p}=0.016)$, body weight $(\mathrm{p}=0.035), \mathrm{BMI}(\mathrm{p}=0.025)$, and $\mathrm{HbA}_{1 \mathrm{C}}(\mathrm{p}=0.0024)$ proved to be significantly different between normal and diabetic patients. Significant difference was found based on HOMA IR between the two groups $1.69 \pm 0.51$ vs $6.46 \pm 1.42 ; \mathrm{p}=0.0017)$. Based on the HEART Score, patients with new onset diabetes mellitus were put into Group 3, which also reflects the risk which diabetes carries for the development of cardiovascular diseases.

Conclusion: Cardiovascular risk can be decreased with increased allograft survival by early diagnosis and management of diabetes. 
Keywords: kidney transplantation, new onset diabetes mellitus, cardiovascular risk factors

Borda B, Szederkényi E, Hódi Z, Ottlakán A, Szabó V, Lázár Gy. [Changes in carbohydrate metabolism after kidney transplantation and their effects on cardiovascular risk]. Orv Hetil. 2017; 158(38): 1512-1516.

(Beérkezett: 2017. június 25; elfogadva: 2017. július 20.)

\section{Rövidítések}

$\mathrm{ADA}=($ American Diabetes Association $)$ Amerikai Diabetes Társaság; $\mathrm{BMI}=($ body mass index $)$ testtömegindex; $\mathrm{CIT}=$ (cold ischemic time) hideg ischaemiás idő; $\mathrm{CV}=$ (cardiovascularis) szív- és érrendszeri; eGFR = (estimated glomerular filtration rate) glomerularis filtrációs ráta; $\mathrm{HDL}=$ (high-density lipoprotein) „jó" koleszterin; HOMA = homeosztatikus modellértékelés; IFG = (impaired fasting glucose $)$ emelkedett éhomi vércukorszint; IGT = (impaired glucose tolerance) csökkent glükóztolerancia; IS = immunszuppresszív; MACE = (major adverse cardiovascular events) súlyos cardialis események; $\mathrm{NODM}=$ újonnan kialakult diabetes mellitus; OGTT = orális glükóztolerancia-terhelés; TC = összkoleszterin

A vesetranszplantáció utáni halálozások oka csaknem 40\%-ban valamilyen cardiovascularis (CV) betegségnek tulajdonítható [1]. Az obesitas, emelkedett éhomi vércukorszint (IFG) vagy diabetes mellitus, 30 feletti testtömegindex (BMI), hypertriglyceridaemia vagy alacsony high-density lipoprotein (HDL), hypertonia, az immunszuppresszív (IS) terápia, a romló vesefunkció és a dohányzás mind magas rizikótényezői a CV-megbetegedések kialakulásának $[1,2]$. Az időben fel nem ismert és nem kezelt cukoranyagcsere-változás nemcsak a CVmortalitást növeli, hanem a vesefunkció romlásához is vezet.

Az American Diabetes Association (ADA) és a Magyar Diabetes Társaság ajánlása alapján diabetes mellitusról akkor beszélünk, ha az éhomi vércukorszint $\geq 7,0 \mathrm{mmol} / 1$ vagy $75 \mathrm{~g}$. Orális glükózterhelést (OGTT) követően a 120. percben mért vércukorérték $\geq 11,1 \mathrm{mmol} / 1$. Csökkent glükóztoleranciáról (IGT) a következő esetben beszélünk: 5,6-6,9 mmol/l közötti érték esetén, normál $(\mathrm{N})<5,6 \mathrm{mmol} / \mathrm{l}$ vagy IGT (két órával az OGTT után) 7,8-11,1 mmol/1 között $[3,4]$. Inzulinrezisztenciáról akkor beszélünk, amikor a homeosztatikus modellértékelés (HOMA-IR) 4,4 feletti.

1. táblázat |Alkalmazott immunszuppresszív terápia

\begin{tabular}{ccccc}
\hline & \multicolumn{2}{c}{+ Mycofenolát mofetil } & \multicolumn{2}{c}{-Mycofenolát mofetil } \\
\cline { 2 - 5 } & $+S$ & $-S$ & $+S$ & $-S$ \\
\hline $\operatorname{Tac}(26)$ & 7 & 9 & 8 & 2 \\
\hline $\operatorname{CsA}(18)$ & 6 & 8 & 3 & 1 \\
\hline
\end{tabular}

$\mathrm{Cs} \mathrm{A}=$ cyclosporin $; \mathrm{Tac}=$ tacrolimus

\section{Célkitüzés}

Vizsgálatunk célja, hogy felmérjük a vesetranszplantáció után a cukoranyagcsere-változásokat és azok rizikófaktorait, valamint a már kialakult diabetes mellitus hatását az allograft funkciójára. Tekintettel arra, hogy a cardiovascularis halálozás vezető ok a vesetranszplantáció után, így a HEART-pontok alapján rizikófelmérést végeztünk.

\section{Módszer}

Vizsgálatunkat 44 beteg bevonásával a Szegedi Tudományegyetem Sebészeti Klinikáján végeztük. Azon betegeket vontuk be, akiknél cadavervese-allotranszplantáció történt, korábban nem volt ismert diabetes mellitusuk, anamnézisükben akut myocardialis infarctus nem szerepelt, 18 évnél idősebbek voltak (nők esetében <60 év, férfiak esetében <55 év), szteroid lökésterápiában nem részesültek.

A betegeknél vizsgáltuk az alkalmazott immunszuppresszív terápiát és azok hatását a szénhidrát-anyagcserére (1. táblázat). Vizsgáltuk az alapadatokat, az életkort (év), a férfi/nő arányt, testsúlyt (kg), testmagasságot, BMI-t $\left(\mathrm{kg} / \mathrm{m}^{2}\right)$, valamint a hideg ischaemiás időt (CIT). Minden betegnél éhomi vércukor-, illetve $\mathrm{HbA}_{1 \mathrm{c}}$-szintmérés történt, majd ezt követően OGTT-t végeztünk, amelynek során $175 \mathrm{~g}$ szénhidrátterhelést követőn a 0 . és a 120. percben mértük a glükóz- és inzulinszinteket.

$\mathrm{Az}$ éhomi vércukor- és inzulinszintekből a HOMA 1 kalkulátor segítségével vizsgáltuk az inzulinrezisztenciát, amely alapján HOMA-IR: éhgyomorra mért vércukor $\times$ éhgyomorra mért inzulinszint/22,5. Inzulinrezisztencia 4,4 feletti érték esetén állt fenn.

A vese funkcióját a szérumkreatinin, karbamid, valamint a glomerularis filtrációs ráta (eGFR) alapján vizsgáltuk. Az eGFR-t a CKD-EPI formula alapján számítottuk, amely figyelembe veszi a beteg kreatininszintjét, életkorát és nemét is.

A cardiovascularis rizikó felmérésére a HEART-pontot alkalmaztuk, amely a szisztolés vérnyomást, dohányzást, összkoleszterint (TC), HDL-t, nemet és az életkort veszi alapul. A CV-rizikó alapján a betegeket három csoportba soroltuk. A 0-3 pont közötti érték - a súlyos cardialis események (MACE) tekintetében - 1,6\%-os kockázatot jelent, ezért a beteg megfigyelése javasolt. A 4-6 pont közötti érték esetén a MACE 13\%-os, ezért megfigyelés és kockázatcsökkentés javasolt. 7 pont felett 50\%-os a kockázat, amely esetben kockázatcsökkentés és a beteg 


\begin{tabular}{lrrlll} 
2. táblázat & HEART-pontok & & \\
& & & & \\
\hline $\begin{array}{l}\text { HEART- } \\
\text { pont }\end{array}$ & $\%$ pts & MACE $/ n$ & MACE & Halálozás & Irányelv \\
\hline $0-3$ & $32 \%$ & $38 / 1993$ & $1,9 \%$ & $0,05 \%$ & Normál \\
\hline $4-6$ & $51 \%$ & $413 / 3136$ & $13 \%$ & $1,3 \%$ & $\begin{array}{l}\text { Megfigyelés, } \\
\text { kockázatkezelés }\end{array}$ \\
\hline $7-10$ & $17 \%$ & $518 / 1045$ & $50 \%$ & $2,8 \%$ & $\begin{array}{l}\text { Megfigyelés, } \\
\text { kezelés }\end{array}$ \\
\hline
\end{tabular}

MACE $=$ súlyos cardialis események

azonnali kezelésének megkezdése szükséges (2. táblázat).

A vizsgálatot a Szegedi Tudományegyetem, Szent Györgyi Albert Klinikai Központ Regionális Humán Orvosbiológiai Kutatásetikai Bizottsága engedélyezte (iktatószám: 18/2017-SZTE). A betegek a vizsgálattal kapcsolatban teljes körú felvilágosítást kaptak.

\section{Statisztikai analízis}

A statisztikai analízis során átlagot és szórást (SD) számítottunk. Normáleloszlású populáció esetén t-próbát alkalmaztunk. Kategorikus változóknál $\chi^{2}$ és Fischer-tesztet alkalmaztunk. Szignifikánsnak a $p<0,05$ értéket tekintettük. A statisztikai analízist az SPSS 15.0. verziójával végeztük.

\section{Eredmények}

Vizsgálataink során a bevont 44 beteget az OGTT 120. percben mért eredményei alapján három csoportba soroltuk: normál szénhidrát-anyagcseréjü betegek $(\mathrm{n}=20$; $45 \%$,), IFG/IGT $(\mathrm{n}=13 ; 29 \%)$, NODM $(\mathrm{n}=11 ; 25 \%)$.

$\mathrm{Az}$ immunszuppresszív terápia tekintetében a tacrolimust szedők körében kilenc betegnél $(34 \%)$ alakult ki NODM, míg a cyclosporint szedőknél mindössze két betegnél (11\%) diagnosztizáltunk diabetest, amelyek között az eltérés szignifikáns volt $(\mathrm{p}=0,017)$.

$\mathrm{Az}$ alapadatok tekintetében a testsúly $(\mathrm{p}=0,035)$, a BMI $(\mathrm{p}=0,025)$, valamint a hideg ischaemiás idő $(\mathrm{p}=$ $0,016)$ a normál szénhidrát-anyagcseréjü és az újonnan kialakult diabetes mellitusos betegek között szignifikánsan különbözött (3. táblázat).

Az inzulinrezisztenciát vizsgálva a HOMA 1 alapján a normál szénhidrát-anyagcseréjü és a diabeteses betegek között szignifikáns különbség volt $(1,69 \pm 0,51$ vs. 6,46 $\pm 1,42 ; \mathrm{p}=0,0017) . \mathrm{A} \mathrm{HbA}_{\mathrm{lc}}$ tekintetében hasonló eredményre jutottunk $(4 \pm 1,75$ vs. $8 \pm 2,78 ; \mathrm{p}=$ $0,0024)$.

A vesefunkciót vizsgálva a normál szénhidrát-anyagcseréjű és diabeteses betegek között a szérumkreatinin$(\mathrm{p}=0,0013)$, az eGFR- $(\mathrm{p}=0,0026)$ és a karbamid$(\mathrm{p}=0,0157)$ értékek szignifikánsan különböztek (4. táblázat).
3. táblázat |Alapadatok a normál szénhidrát-anyagcseréjủ és diabeteses bete gek között

\begin{tabular}{|c|c|c|c|c|}
\hline & $\begin{array}{l}\mathrm{N} \\
(\mathrm{n}=20) \\
\text { átlag } \pm \mathrm{SD}\end{array}$ & $\begin{array}{l}\text { IFG/IGT } \\
(\mathrm{n}=13) \\
\text { átlag } \pm \text { SD }\end{array}$ & $\begin{array}{l}\text { NODM } \\
(\mathrm{n}=11) \\
\text { átlag } \pm S D\end{array}$ & $\begin{array}{l}\text { p-érték } \\
(\mathrm{N} \text { vs. } \\
\text { NODM) } \\
\text { átlag } \pm \mathrm{SD}\end{array}$ \\
\hline Életkor (év) & $48 \pm 3,82$ & $50 \pm 5,42$ & $53 \pm 2,67$ & 0,568 \\
\hline Testsúly (kg) & $79 \pm 4,82$ & $75 \pm 5,67$ & $89 \pm 6,89$ & 0,035 \\
\hline $\begin{array}{l}\text { Testmagasság } \\
(\mathrm{cm})\end{array}$ & $171 \pm 3,18$ & $163 \pm 2,36$ & $165 \pm 4,23$ & 0,345 \\
\hline $\mathrm{BMI}\left(\mathrm{kg} / \mathrm{m}^{2}\right)$ & $24 \pm 2,39$ & $26 \pm 1,37$ & $30 \pm 2,35$ & 0,025 \\
\hline $\mathrm{HbA}_{1 \mathrm{c}}(\%)$ & $4 \pm 1,75$ & $6 \pm 3,72$ & $8 \pm 2,78$ & 0,0024 \\
\hline $\begin{array}{l}\text { HOMA } 1 \\
\text { index }\end{array}$ & $1,69 \pm 0,51$ & $2,3 \pm 0,89$ & $6,46 \pm 1,42$ & 0,0017 \\
\hline CIT (h) & $9 \pm 3,64$ & $11 \pm 3,92$ & $15 \pm 2,89$ & 0,016 \\
\hline $\begin{array}{l}\text { Dohányzás } \\
\text { (igen/nem) }\end{array}$ & $8 / 12$ & $5 / 8$ & $9 / 2$ & 0,024 \\
\hline $\mathrm{TC}(\mathrm{mmol} / \mathrm{l})$ & $1,7 \pm 0,51$ & $2,4 \pm 0,62$ & $4,8 \pm 1,83$ & 0,0037 \\
\hline $\begin{array}{l}\text { Szisztolés } \\
\text { vérnyomás } \\
(\mathrm{Hgmm})\end{array}$ & $115 \pm 5,72$ & $125 \pm 7,82$ & $145 \pm 6,43$ & 0,0267 \\
\hline
\end{tabular}

$\mathrm{BMI}=$ testtömegindex CIT $=$ hideg ischaemiás idő; HOMA = homeosztatikus modellértékelés; IFG = emelkedett éhomi vércukorszint; IGT = csökkent glükóztolerancia; $\mathrm{N}=$ normál; $\mathrm{NODM}=$ újonnan kialakult diabetes mellitus; OGTT = orális glükózterhelés; TC = összkoleszterin

4. táblázat |Vese funkcionális változások a normál szénhidrát-anyagcseréjü és diabeteses betegek között

\begin{tabular}{lllll}
\hline & $\begin{array}{l}\mathrm{N} \\
(\mathrm{n}=20)\end{array}$ & $\begin{array}{l}\text { IFG/IGT } \\
(\mathrm{n}=13)\end{array}$ & $\begin{array}{l}\text { NODM } \\
(\mathrm{n}=11)\end{array}$ & $\begin{array}{l}\text { p-érték } \\
(\mathrm{N} \text { vs. } \\
\text { NODM })\end{array}$ \\
\hline $\begin{array}{l}\text { Szérum- } \\
\text { kreatinin } \\
(\mu \mathrm{mol} / \mathrm{l})\end{array}$ & $\mathbf{1 0 8} \pm \mathbf{8 , 9 2}$ & $\begin{array}{l}149 \pm \\
12,38\end{array}$ & $\begin{array}{l}\mathbf{1 7 8} \pm \\
\mathbf{1 5 , 7 8}\end{array}$ & $\mathbf{0 , 0 0 1 3}$ \\
\hline $\begin{array}{l}\mathrm{eGFR}(\mathrm{ml} / \\
\left.\mathrm{min} / 1,73 \mathrm{~m}^{2}\right)\end{array}$ & $\mathbf{5 7 \pm 2 , 6 2}$ & $45 \pm 3,79$ & $\mathbf{3 1} \pm \mathbf{4 , 7 9}$ & $\mathbf{0 , 0 0 2 6}$ \\
\hline $\begin{array}{l}\text { Karbamid } \\
(\mu \mathrm{mol} / \mathrm{l})\end{array}$ & $\mathbf{4 \pm 2 , 6 3}$ & $5 \pm 3,15$ & $\mathbf{1 1} \pm \mathbf{2 , 7 3}$ & $\mathbf{0 , 0 1 5 7}$ \\
\hline
\end{tabular}

eGFR = glomerularis filtrációs ráta; IFG = emelkedett éhomi vércukorszint; IGT = csökkent glükóztolerancia; NODM = újonnan kialakult diabetes mellitus

Vizsgálatunk során azt tapasztaltuk, hogy az OGTT-t követő 120. percben mért vércukorérték emelkedésével a szérumkreatinin-szint együtt emelkedik (1.ábra).

Cardiovascularis rizikófelmérés tekintetében a TC $(1,7 \pm 0,51$ vs. $4,8 \pm 1,83 ; \mathrm{p}=0,0037)$ és a szisztolés vérnyomás ( $115 \pm 5,72$ vs. $145 \pm 6,43 ; p=0,0267)$ szignifikánsan különbözött a normál szénhidrát-anyagcseréjü és diabeteses betegek között.

A HEART-pont alapján 1. csoport 0-3 rizikójú csoportba 25 beteget, a 2 . csoport 4-6 rizikójú csoportba 11 beteget, míg a 3 . csoport $\geq 7$ rizikójú csoportba nyolc 


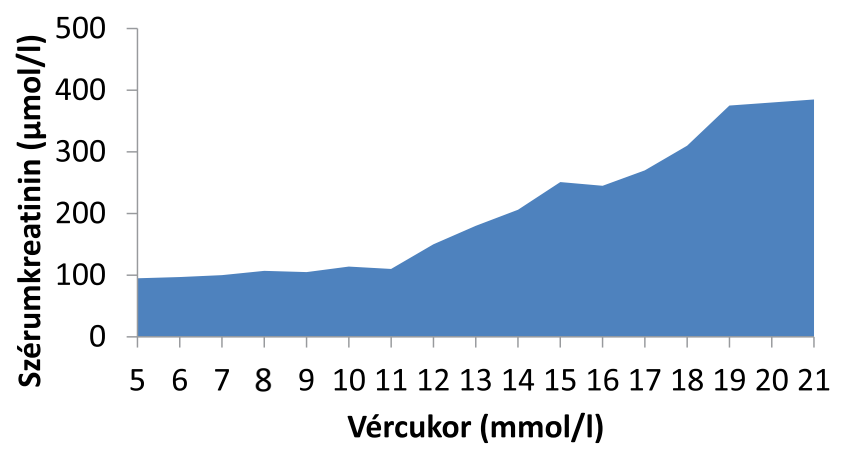

1. ábra

Szérumkreatinin változása az OGTT-t követően a 120 . percben mért vércukorszint függvényében

beteget soroltunk. Kiemelendő, hogy míg a HEARTpontrendszer nem veszi figyelembe a cukoranyagcserét, a saját beteganyagunkban a harmadik csoportba sorolt betegek közül minden beteg az újonnan kialakult diabetes mellitusos csoportból került ki.

\section{Megbeszélés}

Betegeinknél a vesetranszplantáció után újonnan kialakult diabetes mellitus OGTT utáni 120. percben mért értékek alapján az előfordulás gyakorisága $25 \%$ volt.

$\mathrm{Az}$ alkalmazott immunszuppresszív szereket vizsgálva a tacrolimust szedők körében 34\%-ban alakult ki diabetes mellitus, míg a cyclosporint szedők körében ennek az aránya 11\%-volt. Vincenti és mtsai [5] vizsgálatában a diabetes gyakorisága a tacrolimus esetében 33,6\%, míg cyclosporin alkalmazását követően $26 \%$ volt.

A betegek alapadatait vizsgálva a normál szénhidrátanyagcseréjü betegek és a diabeteses betegcsoportok között a BMI $(\mathrm{p}=0,025)$, a testsúly $(\mathrm{p}=0,035)$, valamint a hideg ischaemiás idő ( $\mathrm{p}=0,016)$ szignifikánsan különbözött. Valderhang és mtsai [6] vizsgálatában a NODAT előfordulási aránya $14 \%$ volt. Romagnoli és mtsai [7] rámutattak arra, hogy a NODAT legfőbb rizikótényezői az immunszuppresszív szerek, de fontos szerepet játszik még a recipiens családi anamnézise, testtömege és BMIje is.

A HOMA 1 alapján számított inzulinrezisztencia-vizsgálat a normál szénhidrát-anyagcseréjü betegek és a diabeteses betegek között szignifikánsan különbözött ( $\mathrm{p}=$ 0,0017). A HbA $\mathrm{lc}_{\mathrm{c}}$-értékek az inzulinrezisztenciához hasonlóan szignifikánsan különböztek a normál szénhidrát-anyagcseréjű betegek és a diabeteses betegek között $(\mathrm{p}=0,0024)$.

A vese funkcionális vizsgálatának tekintetében, Türk és munkatársaiboz [8] hasonlóan, mind a szérumkreatinin$(\mathrm{p}=0,0013)$, az eGFR- $(\mathrm{p}=0,0026)$, valamint a karbamid- $(\mathrm{p}=0,0157)$ értékek is magasabbak voltak a diabeteses betegek körében, összehasonlítva a normál szénhidrát-anyagcseréjü betegekkel, amely két csoport között a különbség szignifikánsnak bizonyult. Schiel és mtsai [9] is rámutattak arra, hogy az obesitas az egyik legfóbb rizikófaktora az újonnan kialakult diabetes mellitusnak $\left(24,0 \pm 8,5\right.$ vs. $\left.21,6 \pm 7,8 \mathrm{~kg} / \mathrm{m}^{2} ; \mathrm{p}=0,077\right)$. Saját klinikai vizsgálatunk rámutatott arra, hogy a vércukorszint emelkedésével a szérumkreatinin-érték együtt $\operatorname{mozog}[10,11]$.

Közismert tény, hogy a transzplantáció utáni halálozások egyik legfőbb oka a cardiovascularis betegségek megléte. Ezek felmérésére a HEART-pontot használtuk, amelynek kiszámításához szükséges adatok - úgymint a triglicerid ( $\mathrm{p}=0,0037)$, a szisztolés vérnyomás ( $\mathrm{p}=$ 0,0267) - szignifikánsan eltértek a normál szénhidrátanyagcseréjü és diabeteses betegek között [8-10]. A HEART-pontszám alapján a harmadik csoportba az újonnan kialakult diabetes mellitusos betegek kerültek, amely tény tükrözi a diabetes cardiovascularis rizikóra gyakorolt hatását.

Ezeket összegezve: Az időben fel nem ismert és nem kezelt diabetes nemcsak a beültetett vesét károsítja, hanem a cardiovascularis kockázatot is fokozza $[1,3,7$, 12]. A vesetranszplantált betegek esetében a graft hoszszú távú túlélése növelhető, a cardiovascularis kockázat pedig csökkenthető a diabetes időben történő felismerésével és kezelésével. A betegek gondozásában és az immunszuppresszív kezelés megfelelő kiválasztásában egyaránt hangsúlyt kell helyezni a rizikófaktorok gondos felmérésére. A magas rizikójú betegek esetén ajánlott kalcineurininhibitor-mentes immunszuppresszív kezelés választása. Fontos a szénhidrát-anyagcsere rendszeres ellenőrzése, különös tekintettel a magas kockázatú betegekre. Abban az esetben, ha a szénhidrát-anyagcsere romlását tapasztaljuk, a beteg diabetológiai gondozásba vétele szükséges és ajánlott. A vesetranszplantált betegek interdiszciplináris gondozását lehetőség szerint centralizáltan, egy gondozói teamnek kell végeznie, vagy amennyiben az másként nem megoldható - legalább évente kontrollvizsgálat elvégzése szükséges, amely során cukorterheléses vizsgálat és a $\mathrm{HbA}_{\mathrm{lc}}$-szint mérése javasolt. Az összehangolt gondozói munka nemcsak az allograft funkciójának megőrzésében, hanem hosszabb távon a macrovascularis szövődmények megelőzésében és a betegek túlélésében is döntő szerepet játszik.

Anyagi támogatás: A közlemény megírása anyagi támogatásban nem részesült.

Szerzôi munkamegosztás: B. B.: A cikk megírása. Sz. E., H. Z.: A hipotézis felállítása. O. A.: Statisztikai elemzés. Sz. V.: A betegek koordinálása. L. Gy.: A kutatómunka irányítása. A cikk végleges változatát valamennyi szerző elolvasta és jóváhagyta.

Érdekeltségek: A szerzőknek nincsenek érdekeltségeik. 


\section{Irodalom}

[1] Ossareh S, Nassem S, Faraji MA, et al. Frequency and risk factors for posttransplant diabetes mellitus in Iranian renal transplant patients. Transplant Proc. 2009; 41: 2814-2816

[2] Burroughs TE, Swindle J, Takemoto S, et al. Diabetic complications associated with new-onset diabetes mellitus in renal transplant recipients. Transplantation 2007; 83: 1027-1034.

[3] American Diabetes Association. Diagnosis and classification of diabetes mellitus. Diabetes Care 2012; 35(Suppl 1): S64-S71.

[4] Jeremendy Gy, Gaál Zs, Gerô L, et al. Health Professional Guidelines - Diagnosis of diabetes mellitus, and antihyperglycaemic treatment and care of diabetics in adulthood. [Egészségügyi szakmai irányelv - A diabetes mellitus kórismézéséről, a cukorbetegek antihyperglykaemiás kezelésérôl és gondozásáról felnóttkorban.] Diabetologia Hungarica 2017; 25: 5-77. [Hungarian ]

[5] Vincenti F, Friman S, Scheuermann E, et al. Results of an international, randomized trial comparing glucose metabolism disorders and outcome with cyclosporine versus tacrolimus. Am J Transplant. 2007; 7: 1506-1514.

[6] Valderhaug TG, Jenssen T, Hartmann A, et al. Fasting plasma glucose and glycosylated hemoglobin in the screening for diabetes mellitus after renal transplantation. Transplantation 2009; 88: $429-434$
[7] Romagnoli J, Citterio F, Violi P, et al. Post-transplant diabetes mellitus: a case-control analysis of the risk factors. Transpl Int. 2005; 18: 309-312.

[8] Türk T, Pietruck F, Dolff S, et al. Repaglinide in the management of new-onset diabetes mellitus after renal transplantation. Am J Transplant. 2006; 6: 842-846.

[9] Schiel R, Heinrich S, Steiner T, et al. Post-transplant diabetes mellitus: risk factors, frequency of transplant rejections, and long-term prognosis. Clin Exp Nephrol. 2005; 9: 164-169.

[10] Borda B, Szederkényi E, Lengyel C, et al. Functional and histopathologic changes in renal transplant patients with new-onset diabetes and dyslipidemia. Transplant. Proc. 2011; 43: 12541258 .

[11] Borda B, Lengyel C, Szederkényi E, et al. Post-transplant diabetes mellitus - Risk factors and effects on the function and morphology of the allograft. Acta Physiol Hung. 2012; 99: 206215.

[12] Luan FL, Steffick DE, Ojo AO. New-onset diabetes mellitus in kidney transplant recipients discharged on steroid-free immunosuppression. Transplantation 2011; 91: 334-341.

(Borda Bernadett dr., Szeged, Semmelweis u. 8., 6720 e-mail: borda.bernadett@med.u-szeged.hu)

"Tandem bona causa triumphat."

(Az igaz ügy végül diadalmaskodik.)

\title{
MEGHÍ Vó
}

\begin{abstract}
A Szent Margit Kórház Intézeti Tudományos és Kutatás Etikai Bizottsága tisztelettel meghívja az érdeklődőket a következő tudományos ülésére, amelyet a Gasztroenterológiai Osztály és az Általános Belgyógyászati Osztály közösen rendez.
\end{abstract}

Időpont: 2017. szeptember 28. (csütörtök) 14:30

Helyszín: Szent Margit Kórház - 1032 Budapest III., Bécsi út 132.

„A” épület, I. emelet, Konferenciaterem

Üléselnök: Prof. Dr. Berényi Marianne, ITKEB elnök

\section{Előadások}

Dr. Demeter Pál: A kolonoszkópia technikai nehézségei

Dr. Juhász Márk: Coeliakia és nem-coeliakiás gluténszenzitivitás

Minden érdeklődőt szeretettel várunk! 